Diabetologia 7, 189-194 (1971)

(C) by Springer-Verlag 1971

\title{
Blood Lipids in Normal and Subdiabetic Rabbits before and after the Induction of Hypercholesterolaemia*
}

\author{
K.F. Wrutimand and B.W. Volk \\ With the Technical Assistance of Z. Dordevro \\ Isaac Albert Research Institute of the Kingsbrook Jewish Medical Center, Brooklyn, New York, UsA
}

Received: October 1, 1970, accepted: March 29, 1971

Summary. Blood lipid values were determined in 48 normal, 56 subdiabetic and 6 overtly alloxan-diabetic rabbits before and after the initiation of experimental hypercholesterolaemia. Subdiabetes, induced by small doses of alloxan or by sequentially administered injections of cortisone and alloxan, is characterized by normoglycaemia changing to hyperglycaemia following repeated, normally nondiabetogenic small cortisone injections. Before cholesterol feeding, the subdiabetic rabbits attained considerably higher cholesterol, phospholipid, nonesterified fatty acid and total lipid. levels than did the metabolically normal animals. The corresponding prefeeding levels of the alloxan-diabetic rabbits were also higher than normal, but their average cholesterol and phospholipid values remained lower than in the subdiabetic animals. During cholesterol feeding, the averages of all lipid fractions, especially in the subdiabetic and alloxan-diabetic animals, rose considerably for 8 weeks; thereafter, they tended to decline but continued to remain abnormally high, and only minor differences between the experimental groups persisted.

Lipides du sang chez des lapins normaux et sub-diabétiques avant et après induction d'hypercholestérolémie

Résumé. Les valeurs des lipides sanguins ont été déterminées chez 48 lapins normaux, 56 lapins sub-diabétiques et 6 lapins manifestement diabétiques par l'alloxane, avant et après l'induction d'une hypercholestérolémie expérimentale. Le sub-diabète, provoqué par de petites doses d'alloxane, ou par des injections séquentielles de cortisone et d'alloxane, est caractérisé par une glycémie normale évoluant vers l'hyperglycémie à la suite de petites injections répétées de cortisone normalement non-diabétogènes. Avant l'administration de cholestérol, les lapins sub-diabétiques atteignaient des taux considérablement plus élevés de cholestérol, de phospholipides, d'acides gras non-estérifiés et de lipides totaux que les animaux métaboliquement normaux. Les taux correspondants (avant l'administration de cholestérol) étaient également plus élevés chez les lapins diabétiques par l'alloxane que chez les lapins normaux, mais leurs valeurs moyennes de cho. lestérol et de phospholipides étaient plus basses que chez les animaux sub-diabétiques. Au cours de l'administration de cholestérol, les moyennes de toutes les fractions lipidiques, spécialement chez les animaux sub-diabétiques et diabétiques par l'alloxane, augmentaient considérablement pendant 8 semaines; par la suite elles avaient tendance à diminuer mais continuaient à rester anormalement élevées, et seulement de petites différences persis. taient entre les groupes expérimentaux.

Blutlipide bei gesunden und subdiabetischen Kaninchen vor und nach induzierter Hypercholesterinämie

Zusammenfassung. Bei 48 gesunden, 56 subdiabetischen und sechs alloxan-diabetischen Kaninchen wurden die Blutlipoidwerte vor und während einer experimentell induzierten Hypercholesterinämie bestimmt. Subdiabetes wurde mit kleinen Alloxandosen oder mit einer Kombination von Cortison und Alloxan erzeugt; subdiabetische Tiere werden nur nach zusätzlichen, normalerweise nicht diabetogenen kleinen Cortisondosen hyperglykämisch. Bereits vor der Verfütterung von Cholesterin wiesen die subdiabetischen Kaninchen deutlich erhöhte Cholesterin-, Phospholipoid-, Fettsäure- und Gesamtlipoidwerte im Blut auf. Auch bei den alloxandiabetischen Tieren waren die entsprechenden Werte erhöht, beim Cholesterin und den Phospholipoiden jedoch weniger eindeutig. Während der ersten acht Wochen der Cholesterinverabreichung stiegen alle Lipoidfraktionen, vor allem bei den subdiabetischen und alloxandiabetischen Tieren, stark an. Danach zeigte sich eine leicht abfallende Tendenz, wobei sich die Unterschiede zwischen den experimentellen Gruppen gleichzeitig verringerten.

Key-words: Blood lipids, rabbits, induction of hypercholesterolaemia.
During the investigation of the effect of induced hypercholesterolaemia on the development of atherosclerosis in metabolically normal and in subdiabetic rabbits, serial blood lipid determinations were performed both before and after the initiation of cholesterol feeding. The subdiabetic state was induced by pretreatment with appropriate doses of cortisone

* Supported by a grant from the National Institutes of Health (A2203) followed by a large dose of alloxan $[20,32,33,34,38]$, or with small doses of alloxan alone [34, 38, 39], and is characterized by persistent normoglycaemia, under ordinary conditions, but by hyperglyceamia (of at least $190 \mathrm{mg} \%$ of glucose) following repeated, usually ineffective (nondiabetogenic) daily injections of small doses of cortisone. While the morphological changes in the aorta, the coronary arteries, the heart and the kidneys of such cholesterol-fed normal and subdiabetic rabbits have been discussed elsewhere [36, 37], 
the blood lipid alterations of these and of additional, similarly treated animals, as well as of a control group of alloxan-diabetic rabbits, will be analyzed in the present report.

\section{Material and Methods}

A total of 110 adult white New Zealand rabbits of both sexes (predominantly males) were utilized. They were divided into four groups.

Group I consisted of 48 rabbits; of these 24 were fed a diet of Purina chow containing $1 \%$ cholesterol. To permit morphologic studies, ten of these rabbits were killed at various intervals and 14 animals were kept alive for the entire four month period of investigation. The remaining 24 rabbits were treated. similarly except that their diet contained $2 \%$ corn oil in addition to $1 \%$ cholesterol.

Group II comprised 28 rabbits. In each of them, a subdiabetic state had been successfully induced by a single injection of alloxan monohydrate $(25 \mathrm{mg} / \mathrm{kg}$ of body weight.) Such a small dose of alloxan fails to elicit hyperglycaemia; however, subsequent small, normally nondiabetogenic daily injections of cortisone acetate $(1 \mathrm{mg} / \mathrm{kg})$, administered for a few days, elevate blood sugar levels to at least $190 \mathrm{mg} \%$ in many rabbits [38, 39]. All 28 animals of this Group showed the described pattern of reaction. Eighteen rabbits received a $1 \%$ cholesterol diet without and ten with the addition of $2 \%$ corn oil. Ten rabbits were kept alive for the entire four months of observation, whereas the remaining 18 animals were killed earlier at various intervals.

Group III consisted of 28 rabbits. They had all been rendered subdiabetic by daily injections of cortisone acetate $(4 \mathrm{mg} / \mathrm{kg}$ body weight) for one week followed by $8 \mathrm{mg} / \mathrm{kg}$ for another week, and by a subsequent single dose of alloxan monohydrate $(200 \mathrm{mg} / \mathrm{kg})$. Hyperglycaemia is induced by the cortisone treatment, but the latter also protects the pancreatic beta cells from the otherwise deleterious effects of a large dose of alloxan [31], so that normoglycaemia ensues within two weeks after the cessation of the cortisone-alloxan pretreatment period. These rabbits are now considered. subdiabetic, since small, normally non-diabetogenic daily injections of cortisone acetate $(1 \mathrm{mg} / \mathrm{kg}$ body weight), administered for a few days, again elicit transient hyperglycaemia of at least $190 \mathrm{mg} \%$ [20, $32,33,34,38,39]$. The 28 rabbits in this group were subdiabetic in the described sense. Diet and killing schedule corresponded to those of Group II.

Group IV comprised six rabbits, each of which received a single intravenous diabetogenic dose of alloxan monohydrate $(150 \mathrm{mg} / \mathrm{kg}$ ) and became permanently hyperglycaemic (blood sugar values of $200 \mathrm{mg} \%$ and above). They were fed a $1 \%$ cholesterol diet and were observed for the entire four month period of investigation.
In addition to their solid diets, all rabbits received $5 \%$ sugar water ad libitum. The blood levels of glucose [25], total cholesterol and cholesterol esters [7], phospholipids [15], nonesterified fatty acids [13] and total lipids [35] were determined in all animals before, as well as at approximately biweekly intervals after the initiation of cholesterol feeding.

\section{Results}

The fasting blood glucose levels of all rabbits, except for those of Group IV (alloxan-diabetic animals) and except for the transient hyperglycaemia elicited in the subdiabetic rabbits (Group II and III) after the initial testing of their metabolic status with small doses of cortisone, stayed within the normal range during the entire experimental period.

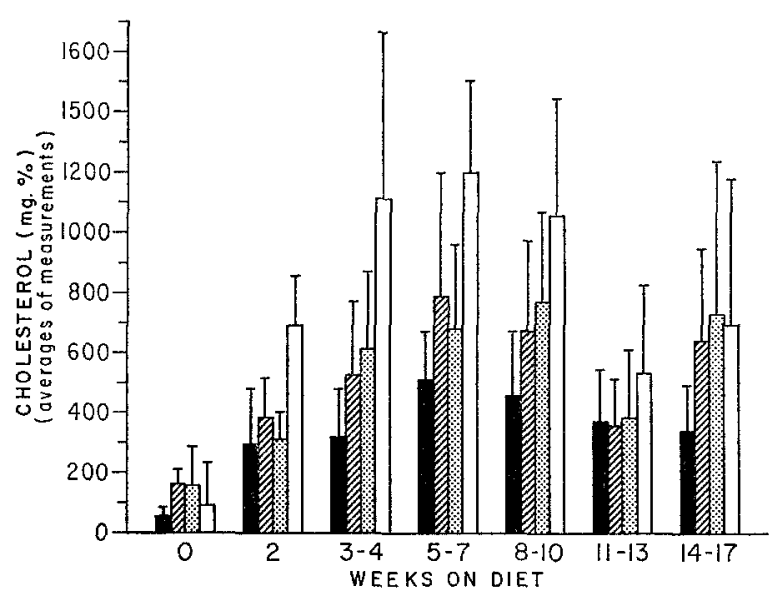

Fig. 1. Blood cholesterol in normal, subdiabetic and diabetic rabbits on cholesterol-containing diet. Left bar: group I (normal); left centre bar: group II (subdiabetic); right centre bar: group III (subdiabetic); right bar: group IV (diabetic). Also recorded are the standard deviations

The blood lipid values for all rabbits are depicted in Fig. 1 to 6. They are recorded as averages of all measurements before and at certain periods after the initiation of the various dietary regimens. In addition to the averages, the standard deviations are also indicated on these graphs. In order to arrive at more meaningful averages based on a greater number of measurements, the results obtained at 3 and at 4 weeks were combined, as were those obtained at 5 , 6 and 7 weeks, at 8,9 and 10 weeks, at 11,12 and 13 weeks, and at 14, 15, 16 and 17 weeks, respectively. Inasmuch as no significant differences of measurements were found among rabbits ingesting cholesterol diets with or without added corn oil, the initially maintained distinction between the subgroups with and without corn oil has been abolished for the purposes of this presentation. 
There were characteristic differences between the four groups in the average levels of cholesterol (Fig. 1), phospholipids (Fig. 3), nonesterified fatty acids (Fig. 5) and total lipids (Fig. 6) before cholesterol feeding was initiated. Both subdiabetic groups (Group II and III) showed considerably higher prefeeding levels of all of these lipid fractions than did the normal animals of Group I. In Group IV (alloxan diabetes), the prefeeding cholesterol and phospholipid values were only moderately elevated above those of the normal rabbits of Group I (Figs. 1 and 3), whereas the nonesterified fatty acid and total lipid levels attained

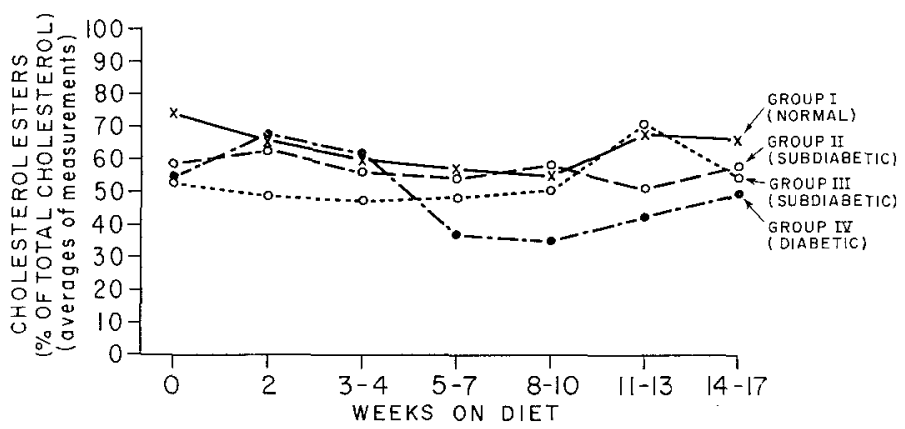

Fig. 2. Percentage of blood cholesterol esters in normal, subdiabetic and diabetic rabbits on cholesterol-containing diet

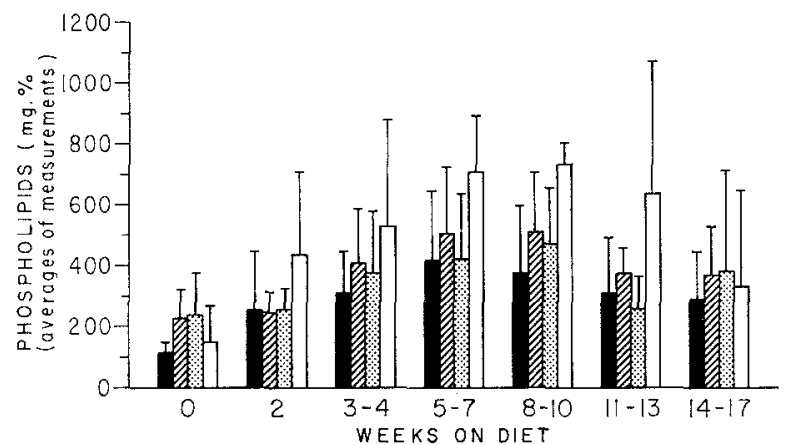

Fig. 3. Blood phospholipids in normal, subdiabetic and diabetic rabbits on cholesterol-containing diet. Left bar: group I (normal); left centre bar : group II (subdiabetic); right centre bar : group III (subdiabetic); right bar: group IV (diabetic). The standard deviations are also recorded

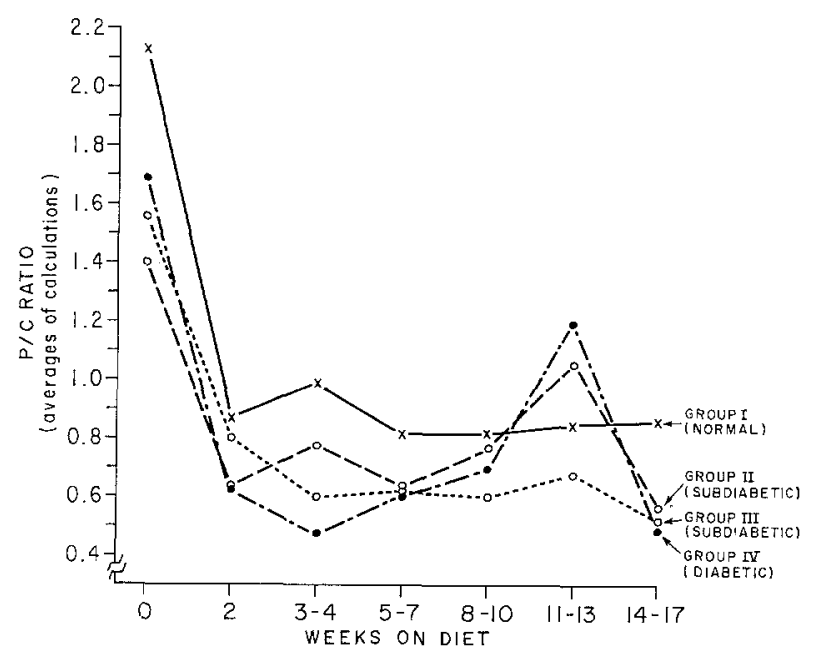

Fig. 4. Blood phospholipid/cholesterol (P/C) ratio in normal, subdiabetic and diabetic rabbits on cholesterol-containing diet

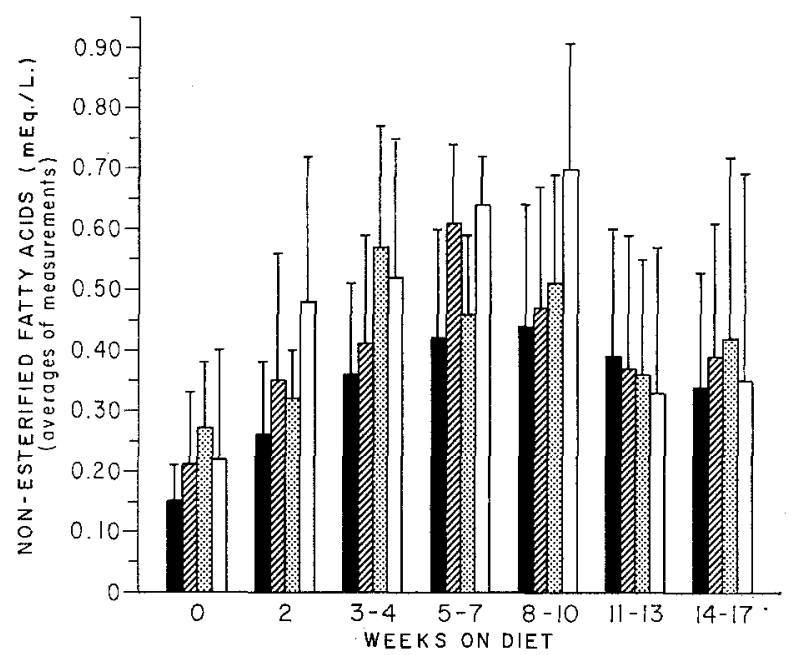

Fig. 5. Nonesterified fatty acids in blood of normal, subdiabetic and diabetic rabbits on cholesterol-containing diet. Left bar : group I (normal); left centre bar: group II (subdiabetic); right centre bar: group III (subdiabetic); right bar: group IV (diabotic). Also recorded are the standard deviations

the same range as those of the subdiabetic animals of Groups II and III (Figs. 5 and 6).

After cholesterol feeding, the averages of all lipid fractions in all four groups became considerably elevated. In general, the values for the subdiabetic animals and especially those of the six alloxan-diabetic rabbits rose to much higher levels than those of the metabolically normal animals. In most cases, the maximal blood lipid values were reached after 7 or 8 weeks of cholesterol feeding; thereafter, they declined to a lower although still abnormally high level (Figs. 1, 3,5 and 6 ). After the tenth week of feeding, consistent major differences in the average blood lipid values between the four experimental groups were no longer 
apparent even though the lipid levels of individual rabbits, especially subdiabetic and alloxan-diabetic ones, often strayed far from the calculated averages of their respective groups.

The average percentages of cholesterol esters, both before and after cholesterol feeding, were generally highest in the normal rabbits of Group I, slightly lower in the two subdiabetic groups, and - except for the first four weeks of cholesterol feeding - lowest in the diabetic animals of Group IV (Fig. 2). The average phospholipid/cholesterol (P/C) ratio before cholesterol feeding was 2.13 in the normal rabbits but distinctly lower in the subdiabetic and alloxan-diabetic animals (Fig. 4). After cholesterol feeding, this ratio fell to below 1.00 in all groups, although transient rises of up to 1.20 were attained in Groups II and IV after 11 to 13 weeks.

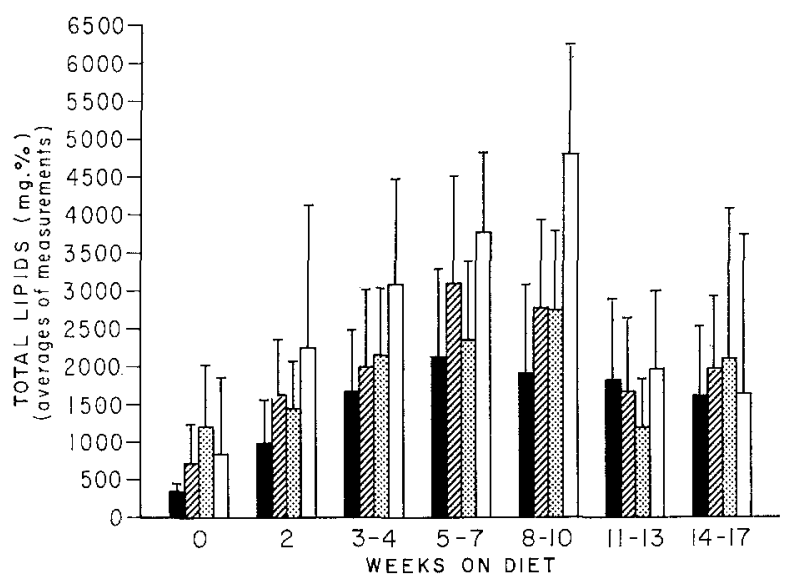

Fig. 6. Total lipids in blood of normal, subdiabetic and diabetic rabbits on cholesterol-containing diet. Left bar : group I (normal); left centre bar : group II (subdiabetic); right centre bar: group III (subdiabetic); right bar : group IV (diabetic). The standard deviations are also indicated

\section{Discussion}

As demonstrated in the present study the subdiabetic state, induced in rabbits by small doses of alloxan alone or by sequentially administered injections of cortisone and alloxan, is associated, per se, with a significant rise in the average blood levels of cholesterol, phospholipids, nonesterified fatty acids and total lipids, and with a moderate decline of the cholesterol ester percentage and of the phospholipid/ cholesterol ratio. Earlier investigations in overtly alloxan-diabetic rabbits have shown a transient hypercholesterolaemia and hyperlipidaemia $[16,28]$, which in a few cases persisted indefinitely [28]. This elevation of serum lipids was thought to be due to the mobilization of fat from the tissue fat depots and was said to be related to the severity of the induced diabetes [28]. The present study demonstrates, however, that hyperlipaemia occurs frequently, although not in- variably, even in rabbits with latent, as well as in those with overt, diabetes.

The recorded elevation of the blood lipid levels in experimental subdiabetes in rabbits is paralleled by the observation that blood lipid values are frequently high normal or increased in human patients with latent $[4,18]$ or manifest $[1,2]$ diabetes, although their rise is usually less pronounced in man with the spontaneous disease than it was in the animals of the experimental model under discussion. Hyperlipaemia in diabetes is caused by insulin deficiency, which in turn was shown to increase fat mobilization from the tissue and, at the same time, to decrease utilization and deposition of circulating lipids $[5,6,14,17,29]$. This may also be the case in the present study since it was demonstrated in previous work from this laboratory that rabbits rendered subdiabetic by one of the two methods employed have low normal or decreased insulin concentrations in both their pancreases and their sera [34, 38].

The blood lipid alterations after cholesterol feeding, as recorded in this experiment, were similar to those observed by others in metabolically normal rabbits $[3,19,26,27,35]$. In all four groups the lipid values of all examined fractions rose sharply to their peaks after about seven or eight weeks, and then tended to decline to a lower albeit still abnormally high level. This decline, or at least the lack of further rise, of the lipid values after the eighth week in spite of continued cholesterol feeding, is associated with, and partially explained by, an increased uptake of lipids from the circulating blood by the various tissues and organs of the body [27]. Also, it is usually after two and more months that cholesterol-induced tissue lesions, such as atherosclerosis [37], hepatosplenomegaly, and cardiac [37] or renal [36] foam cell deposits become most conspicuous in these animals. The cholesterol-fed, subdiabetic and diabetic rabbits continued to display higher lipid values than the metabolically normal animals, although these differences tended to become less distinctive with continued feeding.

In an effort to explain the unexpectedly observed retardation, in time and degree, of cholesterol-induced atheromatosis in alloxan-diabetic rabbits $[9,10,11$, 12], Duff et al. [11, 12] and others [22, 24] suggested that a lowering of the phospholipid/cholesterol $(\mathrm{P} / \mathrm{C})$ ratio in the plasma parallels the degree of atherosclerosis present and that alloxan prevents or diminishes the lowering of this ratio, thus also retarding the development of atherosclerosis. In our six alloxan-diabetic rabbits, the average $\mathrm{P} / \mathrm{C}$ ratio was only somewhat lower than normal before cholesterol feeding but fell sharply thereafter to levels even below those of metabolically normal rabbits (Fig. 4). In the six alloxandiabetic rabbits, aortic atherosclerosis was extensive in only one individual confirming the experience of the authors just quoted. However, the $\mathrm{P} / \mathrm{C}$ ratio of this particular animal, before and after cholesterol feeding, was not significantly different from the $\mathrm{P} / \mathrm{C}$ 
ratios of the five alloxan-diabetic rabbits with no or with only minimal atherosclerosis. In the subdiabetic animals, too, a considerable diminution of the $\mathrm{P} / \mathrm{C}$ ratio, before and especially after cholesterol feeding, took place, but the degree of atherosclerosis in this group as well as in the metabolically normal rabbits was also unrelated to the calculated $\mathrm{P} / \mathrm{C}$ ratios. These observations, therefore, suggest that a factor, or factors, other than the $\mathrm{P} / \mathrm{C}$ ratio of the blood are responsible for the development or retardation of aortic atherosclerosis in normal, subdiabetic or overtly diabetic rabbits. The data at hand in this series offer no clue as to what these factors might be.

As the subdiabetic animals of this experiment all received cortisone as part of their pretreatment, and because cortisone is known to alter the blood lipid composition $[8,23]$, similar cortisone-related changes might also be expected in these animals. However, cortisone was administered for short periods of time and often in small doses only, and cholesterol feeding did not begin until after the cessation of cortisone treatment. It is, therefore, felt that the possible effects, if any, of the cortisone pretreatment on the results presented in this report are very likely negligible.

Latent diabetes in man in characterized by the appearance of hyperglycaemia only after exogenous or endogenous provocation. Experimental subdiabetes in rabbits, as induced in this laboratory, is defined in analogous terms. The present study shows basic similarities between the two conditions with regard to the observed blood lipid alterations, adding to the usefulness of this induced animal disease as a model for the investigation of latent diabetes in the human patient.

\section{References}

1. Adlersberg, D., Eisler, L.: Circulating lipids in diabetes mellitus. J. Amer. med. Ass. 170, 1261-1265 (1959).

2. Albrink, M.J., Man, E.B.: Serum triglycerides in health and diabetes. Diabetes 7, 194-201 (1958).

3. Beaumont, J.L., Grosgogeat, Y., Richard, J.L., Claude, J.R.: La teneur en cholestérol de l'aorte et d'autres organes chez le lapin nourri avec du cholestérol. J. Atheroscler. Res. 3, 210-221 (1963).

4. Braunsteiner, H., Di Pauli, R., Sailer, S., Sandhofer, F. : Hyperlipämie und latenter Diabetes. Klin. Wschr. 43, 715-717 (1965).

5. Butcher, R.W., Baird, C.F., Sutherland, E.W.: Effects of lipolytic and antilipolytic substances on adenosine-3',5'-monophosphate levels in isolated fat cells. J. biol. Chem. 243, 1705-1712 (1968).

6. - Sneyd, J.G.T., Park, C.R., Sutherland, E.W., Jr.: Effect of insulin on adenosine- $3^{\prime}, 5^{\prime}$-monophosphate in rat epididymal fat pad. J. biol. Chem. 241, 1651-1653 (1966).

7. Chiamori, N., Henry, R.J. : Study of the ferric chloride method for determination of total cholesterol and cholesterol esters. Amer. J. clin. Path. 31, 305-309 (1959).

8. Courtice, F.C., Munoz-Mareus, M.: The composition of the plasma lipoproteins in experimental hyperlipae- mia induced by Triton WR-1339, cortisone, alloxan and haemorrhage in rabbits. Quart. J. exp. Physiol. 49, $430-440$ (1964).

9. Duff, G.L., McMillan, G.C.: The effect of alloxan diabetes on experimental cholesterol atherosclerosis in the rabbit. I. The inhibition of experimental cholesterol atherosclerosis in alloxan diabetes. J. exp. Med. 89, 611-621 (1949).

10. - - The effect of alloxan diabetes on experimental cholesterol atherosclerosis in the rabbit. II. The effect of alloxan diabetes on the retrogression of experimental cholesterol atherosclerosis. J. exp. Med. 89, 621630 (1949).

11. - Payne, T.P.B.: The effect of alloxan diabetes on experimental cholesterol atherosclerosis in the rabbit. III. The mechanism of the inhibition of experimental cholesterol atherosclerosis in alloxan-diabetic rabbits. J. exp. Med. 92, 299-317 (1950).

12. - McMillan, G.C.: Pathology of atherosclerosis. Amer. J. Med. 11, 92-108 (1951).

13. Duncombe, W.G.: The colorimetric micro-determination of non-esterified fatty acids in plasma. Clin. Chim. Acta 9, 122-125 (1964).

14. Gries, F. A., Oberdisse, K.: Fettstoffwechselstörungen und Diabetes mellitus. Dtsch. med. Wschr. 95, 727734 (1970).

15. Hawk, P.B., Oser, B.L., Summerson, W.H. : Practical Physiological Chemistry, 13 th Edition, pp. 589-590. New York and Toronto: Blakiston Company, Ine. 1954.

16. Kendall, F.E., Meyer, W., Lewis, L., Victor, J.: Alloxan diabetes in rabbits: production of hypercholesterolemia, hyperlipemia and adrenal cortical lesions. Proc. Soc. exp. Biol. Med. 60, $190-195$ (1945).

17. Kessler, J.I.: Effect of insulin on release of plasma lipolytic activity and clearing of emulsified fat intravenously administered to pancreatectomized and alloxanized dogs. J. Lab. clin. Med. 60, 747-755 (1962).

18. Kremer, G.J., Niemezik, H., Knick, B.: Coronarsklerose und subklinischer Diabetes mellitus. Schweiz. med. Wschr. 97, 735-739 (1967).

19. Kuntz, A., Sulkin, N.M.: Lesions induced in rabbits by cholesterol feeding, with special reference to their origin. Arch. Path, 47, 248-260 (1949).

20. Lazarus, S.S., Volk, B.W.: Studies on a latent diabetic state in cortisone-alloxan treated rabbits. Diabetes 13, $54-59(1964)$.

21. McGill, H.C., Jr., Holman, R.L.: The influence of alloxan diabetes on cholesterol atheromatosis in the rabbit. Proc. Soc. exp. Biol. Med. 72, 72-75 (1949).

22. Moore, J.H., Williams, D.L.: The relationship between diet, plasma lipid composition and aortic atherosis in rabbits. Brit. J. Nutr. 18, $431-448$ (1964).

23. Moran, T.J.: Cortisone-induced alterations in lipid metabolism: morphologic and serologic observations in rabbits. Arch. Path. 73, 300-312 (1962).

24. Nath, M.C., Deshmukh, K.S., Siddiqui, N.F.: Disturbance of cholesterol metabolism in alloxan diabetes and its prevention by glucose-cycloacetoacetate. Proc. Soc. exp. Biol. Med. 126, 737-739 (1967).

25. Nelson, N.: Photometric adaptation of Somogyi method for determination of glucose. J. biol. Chem. 153, $375-380$ (1944).

26. Parker, F., Odland, G.F.: Experimental xanthoma: a correlative biochemical, histologic, histochemical, and electron microscopic study. Amer. J. Path. 53, 537565 (1968).

27. - Peterson, N., Odland, G.F.: A comparison of cholesterol-ester fatty acid patterns in the blood and in evolving xanthoma and atheroma during cholesterol-feeding of rabbits. J. invest. Derm. 47, 253-259 (1966). 
28. Payne, T.P.B., Duff, G.L.: Serum lipids and their fractionation in alloxan diabetes in the rabbit. Proc. Soc. exp. Biol. Med. 73, 332-337 (1950).

29. Raben, M.S., Hollenberg, C.H.: Effect of glucose and insulin on the esterification of fatty acids by isolated adipose tissue. J. clin. Invest. 39, 435-439 (1960).

30. Van Slyke, D.D., Plazin, J.: The preparation of extracts of plasma lipids free from water-soluble contaminants. Clin. Chim. Acta 12, 46-54 (1965).

31. Volk, B.W., Lazarus, S.S.: Protection by cortisone pretreatment against alloxan diabetes. Arch. Path. 73, 363-370 (1962).

32. - - Wellmann, K.F.: Beta cell structure in latent and chronic diabetes of the rabbit. Diabetes 14, 792804 (1965).

33. - Wellmann, K.F., Lazarus, S.S.: Fine structure of rabbit pancreatic $B$ cells in cortisone-alloxan induced subdiabetes. Lab. Invest. 14, 1375-1391 (1965).

34. - - - Brancato, P. : Beta cell morphology and insulin immunoassay in long-term subdiabetic rabbits. Arch. Path. 88, 413-422 (1969).

35. Wang, C. I., Strauss, L., Adlersberg, D. : Experimental xanthomatosis in the rabbit. Arch. Path. 63, 416-422 (1957).
36. Wellmann, K.F., Volk, B.W.: Renal changes in experimental hypercholesterolemia in normal and in subdiabetic rabbits. I. Short term studies. Lab. Invest. $22,36-49(1970)$.

37. - - Experimental atherosclerosis in normal and subdiabetic rabbits. I. Short term studies. Arch. Path. $\mathbf{9 0}, 206-217(1970)$

38. - Brancato, P., Lazarus, S.S., Volk, B.W.: Rabbit beta cell ultrastructure and insulin radio-immunoassay in experimental subdiabetes. Arch. Path. 84, $251-263(1967)$.

39. - Volk, B.W., Lazarus, S.S.: Ultrastructural pancreatic beta-cell changes in rabbits after small and large doses of alloxan. Diabetes 16, 242-251 (1967).

Professor B.W. Volk, M.D.

Isaac Albert Research Institute

Kingsbrook Jewish Medical Center

Rutland Road and East 49 th Street

Brooklyn, New York 11203

USA 